\title{
State Funding of Public Institutions in Nigeria: Control Mechanisms and Legal Challenges (Schools and Hospitals)
}

\author{
Theresa U Akpoghome* \\ Theophilus Chinedu Nwano*
}

\section{A. Abstract}

State funding of public institutions in Nigeria, the control mechanisms and legal challenges forms the basis for this discussion. Attention of the paper is on education and health or schools and hospitals. State funding of public institutions such as schools and hospitals is very crucial for the development of any nation. The wealth of any nation is measured by how healthy the citizens are and human capital development is measured also by the quality of education the masses are receiving. Where these crucial institutions are not adequately funded, such a nation is bound to be in crises. It is in this light that the paper examines the sources of funding, the control mechanisms and the legal challenges. The paper finds that funding comes largely from the annual budget of government. There are other sources such as contribution from international donors and contributory schemes in forms of insurance from workers. The paper notes that Audit is an effective control mechanism and examines the effectiveness of the Supreme Audit Institutions in Nigeria. It also identifies the role of the Public Account Committee in ensuring transparency and accountability in public expenditure. The paper further discusses the challenges and notes that low budgetary allocation, lack of due process in public procurement, corruption, weak institutions, unstable economic policies and lack of effective political and democratic environment contributes to poor funding of public institutions. The paper also notes that the non justiceability of right to education and health is not healthy for Nigeria. Based on the findings, the paper recommends among others that government should increase budgetary allocation to the sectors to meet the AU and UNESCO standards and move the right to education and health to chapter $I V$ of the Constitution as it would enable citizens hold government accountable.

Key Words: Funding; State; Control Mechanisms; Challenges; Corruption; Budget; Due Process

* Akpoghome, Theresa U, PhD, LL.M, LL.B, BL., Professor, Department of Public Law, Faculty of Law, Benson Idahosa University, Benin City, Edo State, Nigeria. E-Mail: teremajor@gmail.com, takpoghome@biu.edu.ng. Ph: +2348065436545,+2348056317472.

* Nwano T. C. PhD, LL.M, LL.B, BL., Lecturer, Department of Public Law, Faculty of Law, Benson Idahosa University, Benin City, Edo State, Nigeria. E-Mail: tnwano@gmail.com, tnwano@biu.edu. ng. Ph: +2348033372420 . 


\section{Introduction}

This paper discusses State funding of public institutions in Nigeria particularly schools and hospitals. This is with a view to determining the legal challenges and control mechanism hindering or promoting the growth of these vital sectors in Nigeria. It is also believed that the paper would proffer useful suggestions that would assist in moving these sectors forward. The provision of adequate medical and health facilities and adequate educational opportunities for the citizens at all levels are provided for in the Constitution of the Federal Republic of Nigeria, ${ }^{1}$ (CFRN) 1999 as amended 2011. If the Constitution provides for health care and education, it behoves on the government to finance these public institutions in addition to other responsibilities it may have. To what extent then has the government lived up to its responsibilities in these regard and are there mechanisms for monitoring compliance and effectiveness and if there are no mechanisms, what could be the challenges? These are the issues that forms the crux of this paper. To address these issues the paper is divided into seven parts. Part I introduces the paper. Part II examines ways of funding public institutions in Nigeria particularly the health and education sectors. Part III examines the sources of revenue for funding public institutions. Part IV discusses the control mechanisms put in place to regulate funds provided for these sectors. Part V examines the challenges of effective funding while part VI makes recommendations and part VII concludes the paper.

\section{Financing the Nigerian Public Institutions}

The need to effectively finance public institutions in Nigeria such as schools and hospitals by the government cannot be overemphasized. This is due to the fact that the primary wealth of a nation is its health while the human capital development cannot be achieved without education. Health care and education in Nigeria is financed by the public and private sectors but this paper primarily focuses on the public sector financing. In Nigeria, the healthcare systems operates in a decentralized pattern. There is the Federal Ministry of Health (FMOH), State Ministry of Health $(\mathrm{SMOH})$ and the Local Government Health Departments (LGHD). The general health policies are formulated by the $\mathrm{FMOH}^{2}$ and through its policy guideline, it coordinates and oversees the activities of the SMOH and the LGHD. The Federal Ministry of Health provides tertiary healthcare through the Teaching Hospitals and Federal Medical Centers.

The State Ministry of Health provides secondary healthcare through the state hospitals while the LGHD provides the Primary Healthcare (PHC) through the primary healthcare centers. Health financing in Nigeria is done through tax revenues, out of pocket payment, donor funding and health insurance schemes. As noted earlier, the financing of the health

1 Sections 17(3) (d) and sections 18(1) (2) (3) (a)-(d), Constitution of the Federal Republic of Nigeria (CFRN) as amended 2011.

2 Section 2, National Health Act, 2014. 
sector is done through tax revenue which represents government expenditure by both federal and state governments including the social insurance contributions. Out of pocket payments are done by individuals and employers while the donor funding comes through bilateral aid programmes or international non-governmental organizations. ${ }^{3}$ The National Health Act has created the Basic Healthcare Provision Fund which shall be financed from the Federal Government Annual Grant of not less than one percent of its consolidated revenue fund, grants by international donor partners; and funds from any other source. ${ }^{4}$

The education sector also largely depends on the income from the government for its funding. In Nigeria, we have the federal schools and state owned schools. The private sector is also not discussed as it is not the focus of this paper although the private sector is a major player in the education sector as its role cuts across all the phases - pre-school, primary, secondary and tertiary. Nigeria has severally witnessed the shutting down of the educational institutions owned and funded by the federal and state government. Nigerian state funded universities reopened for academic activities on the $8^{\text {th }}$ of February 2019 after a 3 months long industrial action by the academic staff to protest the state of infrastructure and unpaid allowances by the government. This trend of government insensitivity in funding education has greatly impacted on the quality of manpower produced in Nigeria. Education like health is funded by government through government revenue accruing from taxes and oil which is the mainstay of the Nigerian Economy.

\section{Sources of Revenue for Financing Education and Health Sectors in Nigeria}

\section{Tax Income/Revenue}

The health and education sectors in Nigeria are primarily funded using the tax based system. These funds are generated through tax at both the federal, state and local government levels but the bulk of the revenue is generated from the sale of oil and gas which is the core of Nigerian economy. The federal government maintains the Federation Account into which all revenues collected by the government of the federation is paid into. ${ }^{5}$ There is also the Excess Crude Account. These accounts are maintained by the federal government and funds are shared to states and local governments in pre-determined sharing formula ${ }^{6}$ which takes into account the population, equality of states, internal revenue generation, land mass, terrain as well as population density. ${ }^{7}$

3 Eke, M., "Challenges of Healthcare Financing in Nigeria", https://www.punchng.com/challenges-ofhealthcare-financing-in-nigeria/ (Last accessed $1^{\text {st }}$ February, 2019).

4 Section 11 (1)(2)(a)-(c) National Health Act, 2014.

5 Section 162(1) CFRN 1999 as amended (2011).

6 Section 162(2) CFRN 1999 as amended (2011).

7 Ibid. 
In the health sector, the states and local government are expected to cater for PHC but this they cannot effectively do, hence, the federal government intervention. ${ }^{8}$ In distributing the funds from the Federation Account, the allocations to the states and local governments are not earmarked or tied to any item specifically and the states and local governments do not submit their budgets to the federal governments so, there are no checks and balances to ensure that funds allocated are effectively utilized. It is only in the National Health Act that we a control mechanism in place. The Act provides thus:

For any state or local government to qualify for a block grant pursuant to sub section (1) of this section, such state or local government shall contribute:

(a) In the case of a state, not less than 25 percent of the total cost of project;

(b) In the case of a local government, not less than 25 percent of the total cost of project as their commitment in the execution of such project. ${ }^{9}$

The Act went further to state that:

The National Primary Healthcare Development Agency shall not disburse money to any -

(a) Local Government Health Authority if it is not satisfied that the money earlier disbursed was applied in accordance with the provisions of this Act,

(b) State or local government that fails to contribute its counterpart funding; and

(c) States and local governments that fail to implement the National Health Policy, norms, standards and guidelines presented by the National Health Council on Health. ${ }^{10}$

Finally, the Act provides that the National Primary Healthcare Development Agency shall develop appropriate guidelines for the administration, disbursement and monitoring of the fund with the approval of the Minister in Council. ${ }^{11}$ By the above provision, the federal government would be able to control the funds allocated to the secondary and primary health services. The bottom line is that funding for education and health is still abysmally low considering Nigeria's position as the giant of Africa. Unlike in the health sector, the federal government does not own any primary school, therefore they do not fund it. They also own less secondary schools -41 Unity schools while the states have 14,000 secondary schools

8 Section 11(3) (b) National Health Act, 2014. It provides that 20 percent of the Basic Health Care provision fund shall be used to provide essential drugs, vaccines and consumables for eligible primary healthcare facilities. 11 (3) (c): 15 percent of the fund shall be used for the provision and maintenance of facilities, equipment and transport for eligible PHC facilities. (d) 10 percent of the fund shall be used for Emergency Medical Treatment of Human Resources for the PHC; and (e) 5 percent of the fund shall be used for Emergency Medical Treatment to be administered by a committee appointed by the National Council on Health.

9 Section 11 (5)(a)-(b) National Health Act 2014.

10 Section 11 (6) National Health Act, 2014.

11 Section 11 (7) National Health Act, 2014. 
and 75,000 primary schools. The federal government also own less number of universities 41 while states own a total of $46 .{ }^{12}$ The resultant effect is that the federal government is underfunding education in Nigeria. Over $90 \%$ of the states are not funding education adequately. ${ }^{13}$ Ultimately, the federal and state governments needs to improve in their funding of education in Nigeria.

\section{Out of Pocket Expenditure}

This involves payment at the point of service delivery. Most Nigerians cannot boast of adequate healthcare because they cannot afford it since they need to pay for the services. Nigerians are made to pay for drugs, medical materials - consumables, consultation and registration fees. Healthcare is not free and same goes for education. Where the government claims that education is free, the pupils/students and their families are still made to pay fees ranging from examination fees (internal and external), tuition (although low).

In the health sector, the National Health Act provides that the Minister may prescribe categories of persons that may be eligible for exemption from payment of health care at public health establishments and in doing this the Minister shall have regard to the range of health services currently available; the categories of persons already receiving exemption from payment for health services; the impact of any such condition on access to health services; and the needs of the vulnerable groups such as women, children, older persons and persons with disabilities. ${ }^{14}$ This has its own challenges that has made it ineffective in Nigeria. ${ }^{15}$

The Act further provides that Nigerians shall be entitled to basic minimum package of health services. ${ }^{16}$ Unfortunately, this provision was not explained as the Act did not specify the content and extent of this basic minimum package. Out of pocket expenditure or user fee was introduced in Nigeria in 1998 under the Bamako initiative which advocated for cost sharing and community participation to increase the sustainability and quality of healthcare. ${ }^{17}$ At inception, it was proposed that out of pocket expenditure will increase the resources available for healthcare and improve efficiency as well as equity to health care. ${ }^{18}$

12 Ndujihe, C., "Education in Free Fall: FG to Declare Emergency", http://www.vanguardngr.com/20 18/04/education-free-fall-government-to-declare-emergency/ (Last accessed $2^{\text {nd }}$ February, 2019).

13 Ibid.

14 Section 3 (1)(2)(a)-(d) National Health Act 2014.

15 Such challenges include the identification of the various vulnerable groups to be eligible, low administrative capacity, willingness on the part of health workers to enforce the policy guidelines and the inconsistency in granting exemptions.

16 Section 3 (3) National Health Act 2014.

17 Babayemi, O., "Public Healthcare Financing in Nigeria: Which Way Forward?" Ann Nigeria Med (2012) Vol. 6, Issue 1, Pp4-10 at 3, https://www.anmjournal.com/articles.asp?2012/6/14/100199. (Last accessed 1st February 2019).

18 World Bank, Financing Healthcare in Developing Countries: An Agenda for Reform (Washington DC: 1987) as cited by Babayemi, Ibid, p 3. 
Whether these propositions have been attained is another issue altogether but the question is whether the out of pocket expenditure should be retained or abrogated? Whether it has improved the resources of the health sector is questionable as it has led many Nigerians to adopt self-medication and consequently reduced access to healthcare.

Again, it should be noted that willingness to pay should not be interpreted to mean "ability to pay". Ability to pay require that poor families would sacrifice their long term economic wellbeing as funds meant for other things would be diverted to healthcare and this has been the trend in Nigeria where you see children drop out of school because their fees have been diverted to funding the healthcare of a sick or infirmed family member. Government at federal and state levels have removed out of pocket expenditure for treatment of ailments such as malaria and immunization for deadly diseases and infections that affect children and adults such as yellow fever, chicken pox, polio, measles etc. Out of pocket expenditure in the education sector is unavoidable as families have decided to shoulder the responsibilities of educating their children. Government schools are poorly funded and remains shut due to industrial actions so, the private institutions are thriving even though they are highly exorbitant and out of the reach of most Nigerians.

\section{Insurance Schemes}

In the health sector, there is the National Health Insurance Scheme (NHIS) which operates within the framework of government regulations. The National Health Act provides that 50 percent of the Basic Health Care Provision Fund shall be used for the provision of basic minimum package of health services to citizens, in eligible primary/or secondary healthcare facilities through the national health insurance scheme. ${ }^{19}$ This scheme was launched in $2005 .^{20}$ Presently, the scheme only covers employees of the federal government and the contribution to the scheme is done in a predetermined formula - the employer contributes $10 \%$ while the employee contributes $5 \%$ bringing the total contribution to $15 \%$ of Basic Salary. ${ }^{21}$ The fraction of the beneficiaries is quite low as it covers only about $3 \%$ of the entire population of over 198 million persons. ${ }^{22}$

\section{Community Based Health Insurance (CBHI)}

This is another way of financing healthcare in Nigeria. It is a form of private health insurance that enables individuals, families, or community groups finance or to finance the cost

19 Section 11 (3) (a) National Health Act 2014.

20 The National Health Insurance Scheme (NHIS) was established by the Federal Government via Act 35 of 1999.

21 Akpoghome, T.U., "Examining the Protection of Access to and Delivery of Healthcare by the National Health Act 2014", Advances in Social Sciences Research Journal (2018), Vol. 5, Issue 6, Pp521-535 at 522 .

22 Ibid. 
of health services. ${ }^{23}$ This scheme is voluntary. The intendment of the government in adopting the CBHI was to use it to cover people employed in the informal sector and the rural area. ${ }^{24}$ This scheme was first implemented in Anambra state in 2003 but due to change in government in 2005 , the scheme became dormant due to lack of support and interest by successive governments. It was also introduced in $\operatorname{Lagos}^{25}$ and Kwara ${ }^{26}$ States of Nigeria. These initiatives are laudable and should be encouraged. There should be awareness in this regard especially in the rural areas as it would enable families contribute according to their abilities.

\section{Donor Funding}

Another source of funding for healthcare is donor funding which is the financial assistance received by developing countries to support socioeconomic and health development. The National Health Act recognizes this aspect of funding in section 11 (2) (b) where it expressly states that the Basic Health fund shall be financed from ... grants by international donor partners. In the education sector, international agencies such as the United Nations Education Scientific and Cultural Organization (UNESCO) is also helping to fund education. The UNESCO in conjunction with the National Open University is working on addressing the barriers to accessing information and knowledge by promoting Open Education Resources (OER). ${ }^{27}$ There is also an ongoing training of 400 youths in the UNESCO Youth Mobile Initiative project with the collaboration of the Federal Capital Territory Administration. ${ }^{28}$

Again, UNESCO disbursed N500, 000 loan to young Nigerians who graduated from the UNESCO 'Tap Project 2018'. ${ }^{29}$ This is geared towards the informal development to reduce unemployment. There have been funding interventions in the education sector from agencies such as the Central Bank of Nigeria (CBN), Petroleum Trust Development Fund (PTDF) and the Tertiary Education Trust Fund (TET Fund). The problem here is that there is no accurate capturing of these funds and they should be included in a coherent frame-

\section{Babayemi, note 17, p3.}

24 Adinma E.D. and Adinma B.J., "Community Based Healthcare Financing: An Untapped Option to a More Effective Healthcare Funding in Nigeria", Niger Med. Journal (2010) Vol.51, Pp95-100.

25 Ayeloso, O. "Lagos Government Introduces Community Based Insurance Scheme", Nigerian Tribune, $13^{\text {th }}$ April 2011, http://www.tribune.com.ng/index.php/insurance/20352-lagos-gove-introduc es-community-based-insurance-scheme. (Last accessed 15th February, 2019).

26 Jimoh, A., "50,000 to Benefit from Community Health Insurance Scheme in Kwara", The Nation, $4^{\text {th }}$ July 2009. http://www.thenationonlineng.net/web2/articles/5669/1/5000-to-benefit-from-comm unity-health-insurance-scheme-in-kwara/page/1.html. (Last accessed 15th February, 2019).

27 “UNECO Promises Continued Support for Nigeria's Education; PM News $6^{\text {th }}$ Feb 2018, https://ww w.pmnewsnigeria.com (Last accessed $15^{\text {th }}$ February 2019).

28 Ibid.

29 Bature, B and Orjime, M., "UNESCO Disburses N500, 000 Loan to Young Nigerians", Leadership Newspapers, 20 August 2018, http://www.leadership.ng/2018/08/20/UNESCO-disburses-500000-1 oan-to-young-nigerians. (Last accessed 15th February 2019). 
work of education funding. ${ }^{30}$ The other challenges with donor funding in Nigeria include but not limited to high cost of technical assistance, donor-driven approach to aid delivery, proliferation of aid agencies, uneven spread of donors' activities, institutional weaknesses and problem of counterpart funding. ${ }^{31}$

\section{Control Mechanism for Public Finance}

In this section we examine some of the control measures put in place by government to ensure that funds spent by the state is actually utilized for the purpose(s) they were meant for. One very crucial mechanism for control in public finance is the audit mechanism and this is addressed hereunder.

\section{a. Audit}

Audit is defined as an official examination of business and financial records to see that they are true and correct. ${ }^{32}$ It has also been defined as an independent examination of the financial statements of an organization with a view to forming an opinion as to the truth and fairness of the statements. ${ }^{33}$ The purpose of audit is to ensure the credibility of financial statements. The Constitution of Nigeria made provision for the office of the Auditor General of the Federation ${ }^{34}$ and the States. ${ }^{35}$ Other documents that provides for the independence of the Auditor General includes: Finance (Control and Management) Act of 1958, ${ }^{36}$ The Financial Regulations of 1976, the Audit Guide, and the Audit Standards and the Civil Service Rules.

The Constitution provides that:

The public account of the Federation and of all offices and courts of the federation shall be audited and reported on by the Auditor - General who shall submit his reports to the National Assembly; and for that purpose, the Auditor-General or any person authorized by him in that behalf shall have access to all the books, records, returns and other documents relating to those accounts. ${ }^{37}$

30 Ndjuihe, note 12.

31 National Planning Commission, The Official Development Assistance Policy 2018, (Abuja: 2008).

32 Hornby, A.S. Oxford Advanced Leaner's Dictionary of Current English, $8^{\text {th }}$ ed., (Oxford: 2009) $\mathrm{p} 82$.

33 Okoro, S.C. and Okafor, G.O., "The Challenges of Public Sector Audit as an Effective Accountability Tool in PPP Arrangements in Nigeria", https:/www.researchgate.net/publication/228285881_t he_challenges_of_Public_Sector_Audit_as_an_Effective_Accountability_Tool_in_PPP_Arrangem ent_in_Nigeria. (Last accessed 2nd February 2019).

34 Section 86 CFRN (1999) as amended 2011.

35 Section 126 CFRN (1999) as amended 2011.

36 Section 24 Finance (Control and Management) Act 1958.

37 Section 85(2) CFRN 1999 as amended 2011. 
It went further to posit that:

The auditor - General shall have power to conduct periodic checks of all government statutory corporations, Commissions, authorities, agencies, including all person and bodies established by an Act of the National Assembly, ${ }^{38}$

... shall within ninety days of receipt of the Accountant General's financial statement, submit his reports under this section to each House of the National Assembly and each House shall cause the reports to be considered by a Committee of the House of the National Assembly responsible for public accounts. ${ }^{39}$

The import of the above for provisions is that the Auditor-General has the power to conduct checks on government agencies and is mandated to review the report of the AccountantGeneral and prepare his own report for consideration by the National Assembly and to be effective, the Constitution also guarantees the independence of the Auditor-General. ${ }^{40}$ This is crucial as no credible audit can be carried out if the Auditor-Generals independence is fettered. These provisions are repeated in the Constitution for states. ${ }^{41}$ So, auditing of the accounts of the federal and state governments is one mechanism for controlling public finance.

\section{b. The Financial Reporting Council (FRC) ${ }^{42}$}

This Council formerly known as the Nigeria Accounting Standards Board is a Federal Government agency established by the Financial Reporting Council of Nigeria Act, No 6, 2011. It is a federal government parastatals and the Federal Ministry of Industry, Trade and investment. The FRC is responsible for developing and publishing accounting and financial reporting standards to be observed in the preparation of financial statements of public entities in Nigeria.

The FRC Act defines the main objectives of the Council to include but not limited to ensuring accuracy and reliability of financial reports and corporate disclosures, pursuant to the various laws and regulations currently in existence in Nigeria; enhance the credibility of financial reporting; and improve the quality of accountancy and audit services, actuarial valuation and corporate governance standards. ${ }^{43}$ The main objective of involving the FRC is to narrow the areas of differences in accounting statement preparation and thus make the financial statements of the various organizations and agencies comparable. ${ }^{44}$

38 Section 85 (4) CFRN 199 as amended 2011.

39 Section 85 (5) CFRN 199 as amended 2011.

40 Section 85 (6) CFRN 1999 as amended 2011.

41 Section 126, 127 and 128 of the Constitution of Nigeria 1999 as amended 2011.

42 The Financial Reporting Council (FRC) of Nigeria Act No. 6, 2011.

43 Financial Reporting Council (FRC), http://www.financialrepoirtingcouncil gov.ng (Last accessed $16^{\text {th }}$ February 2019).

44 Okoro, and Okafor, note 33. 


\section{c. International Public Sector Accounting Standards (IPSAS)}

The accrual IPSAS is based on International Financial Reporting Standards (IFRS) issued by the International Accounting Board (IABS) where the requirements of those standards are applicable to public sector. All Public Sectors were expected to start the implementation of accrual IPSAS by January 2014. ${ }^{45}$ The Federal Executive Council in Nigeria (FEC), approved the adoption of IFRS and IPSAS for both private and public sectors in July $2010 .{ }^{46}$ The goal of this adoption is to enhance and strengthen the country's financial reporting standards in line with international best practices. ${ }^{47}$ IPSAS was developed by the public sector committee of International Federation of Accountants (IFAC) to guide government entities in the preparation of high quality financial reports.

IFAC encourages public sectors to adopt accrual basis of accounting for their general purpose financial statement in order to ensure uniformity and comparability of financial reporting across countries. ${ }^{48}$ One very important aspect of IPSAS is that it would eliminate the cash and cash moderated based accounting which does not allow the obtaining of necessary information in order to provide better support for planning and managing resources and more generally for the decision making processes allowing greater accountability, even between entities. ${ }^{49}$ It is opined that IPSAS seeks to promote transparency in public sector financial reporting across jurisdictions and the conceptual framework is similar to that of IFRS used in the private sector to enhance transparency of operation. ${ }^{50}$

\section{d. Public Accounts Committee of the National Assembly}

The Public Accounts Committee (PAC) is headed by the opposition members in both chambers of the National Assembly. ${ }^{51}$ It is responsible for monitoring accountability and transpa-

45 "International Public Sector Accounting Standing (IPSAS)" https://www.eprints.convenantunivers ity.educ.ng. (Last accessed $16^{\text {th }}$ February 2019).

46 Olayinka, E et al, "International Public Sector Accounting Standards (IPSAS) Adoption and Quality of Financial Reporting in the Nigerian Public sector", ESUT Journal of Accountancy (2016), Vol. 7, No. 2, p 23.

47 Otunla, J. "Federal Government Sets December Deadline for IPSAS Adoption", (2012) http://ww w.thisdaylive.com (Last accessed $16^{\text {th }}$ February 2019).

48 Udeh, F. and Sopekan, S, "Adoption of IPSAS and the Quality of Public Sector Financial Reporting in Nigeria, Research Journal of Finance and Accounting, (2015), Vol.6, No. 20, Pp 1-9.

49 Christiansen J. et al "The Effect of IPSAS on Reforming Governmental Financial Reporting: An International Comparison", International Review of Administrative Sciences, (2013), Vol. 76, p 537-534.

50 Olayinka, note 46, p 24.

51 Owete, F et al "Special Report: How National Assembly's Public Account Committee Engage in Massive Money Laundering" January 24 2016, Premium Times http://www. Premiuntimesng.com (Last accessed $16^{\text {th }}$ February 2019). 
rency in the conduct of government business ${ }^{52} \mathrm{PAC}$ is the only Committee of the National Assembly mentioned in the Constitution. ${ }^{53}$ The responsibilities of the Committee as stated by the Senate Standing Order include:

i) to examine the accounts showing the appropriation of the sums granted by the Senate to meet the public expenditure together with the Auditor-Generals report thereon. The Committee shall, for the purposes of discharging that duty have power to send for any person, papers and records from time to time to the Senate and to sit notwithstanding the adjournment of the Senate;

ii) the Committee shall have power to examine any accounts or report of statutory Corporations and Boards after they have been laid on the table for the Senate and to report thereon from time to time to the Senate; and

iii) The Committee shall have power to enquire into the report of the Auditor-General of the federation with respect to any prepayment audit query which had been overruled by the Chief Executive of the Ministry, Extra Ministerial Departments or Agency of the federal government and courts of the Federation and to report same to the Senate. ${ }^{54}$

The functions listed above is repeated in section 122 of the House of Representatives Standing Order.

Furthermore, the Public Accounts Committee Act 1987 expressly provides for the functions of the Committees. ${ }^{55}$ The above mechanisms have been put in place to control public finance and ensure transparency in the accounts or financial records of the government. These Supreme Audit Institutions (SAIs) may not have performed optimally due to some challenges and that would form the core of the next section of this paper.

\section{Challenges of State Funding of Public Institutions}

Having examined the control mechanisms for public finance of institutions and considering the fact that public institutions such as hospitals and schools are in near total decay stages, one wonders what could be responsible for their current state. This section would articulate the legal challenges albeit briefly. Some of these challenges include inadequate budgetary allocation, limited institutional capacity, corruption, and lack of due process in public procurement, unstable economic and political environment. These are discussed seriatim:

52 Ibid.

53 Section 85(5) CFRN 1999 as amended 2011.

54 Order XIII, Rule 97(5) of the Senate Standing Orders 2007 as amended.

55 Section 4, Public Accounts Committee Act, 1987. 


\section{Budgetary Allocations}

Inadequate or poor funding has been identified as the major reason for the rot and decay in the health and education sectors. In both sectors, there have been strikes which have led to brain drains in these sectors. The federal government's allocation to the educations sector in the last ten years has been poor and miserly. Out of a budget of N55.19 trillion only N3.90 billion or 7.07 percent has been allocated to education. A breakdown of the allocation is as represented below - in 2009, education received N221.19 billion ( 7.25 percent) out of N3.049 trillion budget. In 2010, it received N249.09 billion (4.83 percent) out of N5.16 trillion.

In 2011, the sector received N306.3 billion (6.16 percent) of the N4.972 trillion budget. In 2012, there was a marginal improvement as it rose to 8.20 percent, 2013 it received 8.55 percent, 2014, 9.94 percent. It took a downward turn in 2015 when it was allocated 7.74 percent. In 2016, President Muhammadu Buhari's first full year in office, the education sector received its second-worst allocation in ten years. The sector received N369.6 billion (4 percent) out of a total of N6.061 trillion budget. In 2017 there was a slight rise to 7.4 percent as it received N550 billion. In 2018 education received N435.1 billion representing 7.04 percent from a total budget of $\mathrm{N} 8.612$ trillion $^{56}$ and in 2019 budget, the education sector is expected to receive N462.2 billion representing 7.02 percent out of a budget of N8.83 trillion. $^{57}$

On the other hand, the Ministry of health gets a paltry sum of N315.62 billion form a budget of 8.83 billion for 2019 meanwhile the legislative arm-the National Assembly would receive N8.6 trillion. ${ }^{58}$ This is an increase from N269.34 billion in 2018, an increase of N46.3 billion. ${ }^{59}$ Over the years, budgetary allocation to the health sector has been poor. In 2015 health sector received 5.78 percent, in 2016 it got $4.13 \%$ and 2017 budget, it received 4.16 percent. In 2018 it dropped to 3.95 percent. ${ }^{60}$ It is important to note that this is still lower than the $13 \%$ recommended by the World Health Organization and the $15 \%$ of the AU Agreement in Abuja in 2001. ${ }^{61}$

56 Nwafor, P., Education Sector gets Paltry N3.9 trillion out of N55.19 trillion in Ten Years" http://w ww.vanguadngr.com. (Last accessed $16^{\text {th }}$ February, 2019).

57 Adedigba, A. "2019 Budget Buhari Propose N462 billion for Education" Premium Times, 18 Dec. 2018, https://www premiumtimes.ng.com. (Last accessed $16^{\text {th }}$ February, 2019).

58 Aderemi, O., “A Look at the Key Figures in Nigeria's 2019 Budget”, https://wwwpulse.ng/finance (Last accessed $16^{\text {th }}$ February 2019).

59 Obokoh, A., 'Health Sector in 2019: Nigeria to Witness Big Initiatives, Improved Cancer CareUHC", Business Day (Nigeria) 4 Jan 2019, https://www.presredader.com/nigeria (Last accessed $16^{\text {th }}$ February, 2019).

60 Akpoghome, note 21 at 524.

61 Ibid. 
While the African Union (AU) countries met in April 2001 and recommended the allocation of at least $15 \%$ of the annual budget of member States to health UNESCO proposed that 15 to 20 percent of annual budgets be earmarked for education. ${ }^{62}$

The World Education Forum 2015 Final Report ${ }^{63}$ noted that most governments fall short of allocating the recommended 20 percent international benchmark of public expenditure needed to bridge education funding gaps. ${ }^{64}$ From the above facts and analysis, it is crystal clear that the health and education sectors in Nigeria are grossly underfunded by the various levels of government. Section 11 (2) (a) of the National Health Act provides that the federal government Annual Grant of not less than one percent of its consolidated revenue fund shall be directed to the Basic Healthcare provision fund. The inability of the federal government to provide for this one percent in the health budget five years down the line is not encouraging.

\section{Limited Institutional Capacity}

Dada opines that the investigations conducted by the World Bank revealed that there are severe constraints in all sectors in sub-Saharan Africa. These are characterized by dearth of skilled staff, weak institutional environment which undermine the proper utilization of existing capacity and inadequate training facilities and limited capacity to satisfy the need of skilled personnel. He further stated that the essential tools required to promote development and the capacity to formulate and implement policies, and to manage the economy are weak or non-existent. ${ }^{65}$ Low capacity building has been identified as the missing link in African's development and the adverse effect of this is shown on the level of national development, basic social services and inappropriate policy formulations. ${ }^{66}$

Weak institutions have been the bane of Nigeria and there is no clear policy on ground to strengthen our institutions. Appointments to most institutions and agencies are not based on merit rather they are based on either ethnic, religious or political affiliations and this has to a great extent reduced productivity and transparency in the operations of these institutions.

62 Leadership Editors,

"Budget 2018: Education and Health Sector", The Punch, June 1 2018, https://www.leadership.ng/ 2018/06/01/budget-2018-education-and-health-sector/ (Last accessed 5th February 2019).

63 Also known as 'The Incheon Declaration.

64 Leadership Editors, note 61.

65 Dada, J. O., "Human Capacity building Challenges Towards Improved Service Delivery in Africa", http://www.unpan1.un.org/aapam/unpan025978..../ (Last accessed $16^{\text {th }}$ February, 2019).

66 Ibid. 


\section{Absence of Due Process Mechanism in Public Procurement}

Public procurement is a very vital tool of public service delivery, good governance and a sustainable economy. Governments around the World spend approximately 12-20 percent of their country's GDP on public procurement. ${ }^{67}$ On the other hand due process implies that governmental activities and businesses should be carried out openly, economically and transparently without favoritism and corruptible tendencies. ${ }^{68}$ To avoid fraudulent practices government must realize that due process is critical to the effective implementation of its policies. Fraudulent practices in the Nigeria public sector is on the increase due to the absence of internal control mechanism and this has resulted in undeserving consequences on the socio-economic development of the country. ${ }^{69}$

Halidu, noted that the bane of financial administration in Nigeria from the oil boom years, has been the existence of structurally weak control mechanisms, which create a variety of loopholes that have tended to facilitate and sustain fraudulent practices. ${ }^{70}$ The learned author further observes that this is coupled with the fact that there is a near total absence of due process in the conduct of public affairs. ${ }^{71}$ The need for all to appreciate that public access to procurement and information is noted to be essential to transparency and helps to create a basis for social audit by interested stakeholders. Public information should be easy to find, comprehensive and user friendly providing information of relevance. ${ }^{72}$ The Organisation of Economic Co-Operation and Development (OECD) further noted that the assessor should be able to verify easy access and the content of information made available to the public. ${ }^{73}$

\section{Lack of Effective Political and Democratic Governance}

Nigeria as a nation has had twenty years of uninterrupted democratic rule but the country continues to face enormous problems due to the actions and inactions of the political class.

67 "National Control Mechanisms, Transparency, Non Discrimination and Procurement", https://ww w.developentfinace.un.org/natural-control-mechnaimsms-transparency-non-discrimination-and-pr ocurement/ (Accessed 1st February, 2019).

68 Ezekwesili, O., "Due process Mechanism and Digital Opportunities", Paper presented. to the University Community at Princess Alexandria Auditorium, University of Nigeria, Nsukka, 2005.

69 Atagboro, E., "Due Process Mechanisms and Fraudulent Practices in Nigeria Public Sector", Acta Universitatis Danubius. Administration (2015), Vol. 7, No. 1, p1.

70 Halidu, I. A, "The Allocative and Accountability Aspects of the Public Budget in Nigeria", being a paper presented at National Population Commission Workshop, (1991) as cited by Atagboro, Ibid.

71 Ibid.

72 Organization for Economic Co-operation and Development (OECD), Integrity in Public Procurement: Good Practice from A - Z (France: 2007).

73 Ibid. 
Dike ${ }^{74}$ opines that Nigerian politicians do not practice ethical politics and their actions do not add any values to the system. There are no checks and balances, therefore injustice, authoritarianism, nepotism and tribalism are rife, adored and glorified..$^{75}$ The learned author further posits that the federal government of Nigeria has undertaken some reforms over the years to revive the sluggish economy, but a review of the reform efforts reveal that the society is deeply corrupt and lacks effective institutions and good governance for successful reforms and sustainable economic growth and development. ${ }^{76}$ Consequently, the nation lacks political leadership that is ready, willing, and politically motivated to address the ills in the economy. The learned author concludes by stating that Nigerian leaders are good at prescribing solutions to the nation's economic problems without providing the institutions to make the economy work. They make high sounding promises without fulfilling them, and more often than not their policies are hastily put together and poorly executed. ${ }^{77}$ The current writer totally agrees and aligns herself with the views of the learned author.

There is also the absence of a genuine democratic system in which electorate could participate without coercion and hold politicians accountable for their actions. This also has its impact on the economy. Success at the polls in Nigeria has been described as a "do or die affair by the politician and this consequently results in massive rigging of elections to the extent that the electorates do not believe that their votes count. The 2019 general elections is supposed to have held on the $16^{\text {th }}$ of February 2019 as scheduled by the Independent National Electoral Commission (INEC). Few hours to the election, it was postponed. Several commentaries have trailed the postponement but top on the list is the grand plan by the ruling party to rig the elections even when INEC announced that the postponement was due to logistics. This postponement is coming after so much resources have been sunk into the preparations. Another massive economic loss from the political class without an apology to the tax payers. Thus, the absence of democratic governance is one of the major causes of Nigeria's weak economy and the rising level of poverty.

No matter the political system Nigeria is running, if a substantial portion of the budget is not devoted to education and vocational training, then we are doomed as a nation because we cannot effectively compete with the rest of the world. There must be a conscious effort to reduce what goes to the political class form the budget.

\section{Inconsistent and Unstable Economic Policies}

It is no news that successive governments in Nigeria do not have the desire to continue the implementation of the economic policies left by their predecessors in office no matter how

74 Dike, V.E, "Governance and Nigeria's Weak Institutions: Is the 2020 Project Achievable", http://w ww.gamji.com/article8000/NEWS8396.htm (Last accessed $5^{\text {th }}$ February, 2019).

75 Ibid.

76 Ibid.

77 Ibid. 
beautiful these policies were. President Olusegun Obasanjo in 1999 introduced the National Economic Empowerment and Development Strategy (NEEDS), Late President Yar'Adua abandoned it for his own 7 Point Agenda and the Vision 2020 project. Jonathan's administration started the SME and YOUWIN initiatives. These were geared towards encouraging businesses to expand so as to employ more people. He had a transformation Agenda while the Buhari Administration came up with the Treasury Single Account (TSA).

The bottom line is that inconsistent and unstable policies are the major causes of the present 'hemorrhage in the economy'. ${ }^{78}$ The value of the naira continues to go down. Today it is N365.2 to $\$ 1$. Even where the apex bank is ready to improve the value of the naira, the control from the executive have made it impossible. It is worthy to note that Dike observes that good momentary policy will correct the anomalies in the economy with effective institution and social infrastructures. ${ }^{79}$

\section{Corruption}

This contributes to poor governance, sociopolitical and economic challenges. Kofele-Kale defines corruption as an act of requesting, offering, giving or accepting directly or indirectly a bribe or any other undue advantage required of the recipient of the bribe and the undue advantage of the prospect thereof. ${ }^{80}$ Corruption has thrived in Nigeria because Nigerians believe that public money belongs to no one. It's a national cake to be shared. Corruption in the health sector leads to the supply of fake or substandard drugs, poor equipment, poor infrastructure, sharing of unallocated budget funds, inflation of contracts, diversion of drugs, selective treatment and appointment hinged on the political affiliation and the use of government time for personal purposes. ${ }^{81}$

In the academic or educational sector, the effect of corruption cannot be over emphasized. Corruption is linked to the lack of infrastructural development, modernization and rehabilitation of schools. There is also a lack of concern for student's services. There are less scholarship programmes and no motivation for students to aim higher in their academic pursuits. The fall in academic standards is linked to corruption as quality has been sacrificed on the altar of mediocrity. Some teachers withhold students' grades until they pay certain amount of money while some lecturers sell copies of textbook extracts. Some students also pay professional examination takers to sit for exams for them. It also a known fact that some well to do families go to the Boards of some examination bodies to buy grades for their children. Incessant absenteeism on the part of teachers is also a sign of corruption.

80 Kofele-Kale, N, The International Law of Responsibility for Economic Crimes: Holding State Officials Individually Liable for Acts of Fraudulent Enrichment, (Hampshire: 2006) as cited by Dike, note 74 .

81 Akpoghome, note 21 p. 523. 
School hours are devoted to personal businesses while the children waste their time in school. $^{82}$

\section{Non Justiciability of Education and Health Rights}

The inability of the citizens of Nigeria to approach the courts for the enforcement of their rights to education and health has contributed to the shoddy attitude of the government in this regard. The Constitution provides that in furtherance of the social order - the State shall direct its policy towards ensuring that: there are adequate medical and health facilities for all persons. ${ }^{83}$ The Constitution further provides that:

Government shall direct its policy towards ensuring that there are equal and adequate educational opportunities at all levels; Government shall promote science and technology and strive to eradicate illiteracy and to this end shall when practicable provide free, compulsory and universal primary education, free university education and free adult literacy programmes. ${ }^{84}$

The phrase "when practicable" in this provision would always provide the opportunity for the government of Nigeria to claim that it is not practicable to provide quality education for citizen.

Apart from this, these provisions in the Constitution is not justiciable as they are contained in chapter 11 of the Constitution titled "Fundamental Objectives and Directive Principles of Stale Policy" as no subject in this chapter can be the subject of litigation in any court in Nigeria. ${ }^{85}$ The African Charter on Human and Peoples Right (ACHPR) in Articles 16 and 17 made provision for the right to health and education.

The Charter provides thus:

1. Every individual shall have the right to enjoy the best attainable state of physical and mental health;

2. Member States to the present Charter shall take the necessary measures to protect the health of their people and to ensure that they receive medical attention when they are sick. ${ }^{86}$

Furthermore, it provides that every individual shall have the right to education. ${ }^{87}$ Nigeria ratified and domesticated the ACHPR but it remained unenforceable for a long time be-

82 See Torulagha, P. S., "The Corrosive Effect of Corruption on Nigerian Educational System", https: $1 /$ www.ganji.com. (Last accessed $16^{\text {th }}$ February, 2019).

83 Section 17(3) (d) CFRN 1999 as amended 2011.

84 Section 18 (1) (2) (3) (a) - (d) CFRN 1999 as amended 2011.

85 Section 6 (6) (c) CFRN 1999 as amended 2011.

86 Article 16 (1) (2) African Charter on Human and Peoples Right (Ratification and Enforcement Procedure) Act, Cap A 9 LFN, 2004.

87 Article 17(1), Ibid. 
cause it contravenes the supremacy clause of the Constitution. ${ }^{88}$ Fortunately, judicial activism in this regard is beginning to yield results although at a very slow pace. Hitherto, Nigerians would proceed to the African Court to seek for the enforcement of this international obligation that she entered into.

\section{Way Forward}

Having articulated the sources, control mechanism and challenges of State funding of public institutions such as schools and hospitals, this section would address the way forward in no particular order. The government is called upon to increase the budgetary allocation to the education and health sectors. Government must strive to attain the $15 \%$ recommendation by the AU for health and UNESCO $20 \%$ for the education sector. Furthermore, the one percent from the federal government consolidated revenue for the basic medical fund for health should be provided for in the health budget.

The right to education and health should be made justiciable by removing these subjects from chapter 11 to chapter IV that deals with fundamental rights. Nigeria has come of age and should invest in these sectors. Judicial activism in this regard should be increased. There is also the need to amend the Constitution to bring it in line with the provisions of the African Charter on Human and Peoples Right which has been domesticated.

Nigeria must invest in capacity building as this would strengthen her institutions for effectiveness and probity. The independence of the Audit institutions and other control mechanisms must be strengthened. The system must be seen to be independent and should be shielded from undue interferences from the Executive. The Public Accounts Committee of the National Assembly must be above board in their scrutiny of public account from the Auditor - General.

Transparency in public procurement and due processes must be upheld at all times. The political class must see their appointments as a call to service and not for self- enrichment. They must be able to develop policies that would turn around the political environmental and make the electorate to have confidence in them. This way, the electorate can demand accountability from public office holders. They must consciously reduce the cost of governance and divert such funds to health and education if Nigeria will remain competitive in the world market. Our politics must be with ethical principles.

Successive governments must ensure that there is continuity in the economic policies of the nation. Inconsistent and unstable economic policies do not help in the growth of public institutions in any country. Infrastructural and institutional challenges must be addressed. Effective mechanisms must be put in place to track and monitor donor funding in the health sector. Healthcare and education funding must be seen as an investment by government and it requires effective management and commitment from the political class to make it profitable. 
The hydra headed monster called corruption must be tackled head on. The manner of fighting corruption in the country leaves much to the desired. The fight is sectarian and used as a weapon to fight opposition and perceived enemies. This trend has entrenched corruption rather than reduce same.

\section{Conclusion}

Achieving State funding of public institutions such as hospitals and schools is dependent on good governance. The Nigerian health and education sectors are lacking full capacity in human development and infrastructure. The health and education sectors are the most important social services of any government. Inadequate funding reduces literacy level and increases the money the government would spend in curbing crimes and other anti-social behaviours which affects the economic growth negatively.

Again, a healthy nation is a wealthy nation and this means that the government at all levels should pay more attention to human capital development by putting mechanisms and coordinated efforts in place to provide Nigerians with standard healthcare and functional education to enable Nigerians to compete effectively in this emerging, knowledge driven world. If our population is growing geometrically without quality education and effective and efficient healthcare system and skills to compete in a globalised world, the large population will become a liability and a major drawback to national aspirations. Nigeria must rise to this responsibility as we cannot afford to play catch up in the world affairs considering her position in Africa.

It is believed that if the recommendation in this paper are implemented, public institutions in Nigeria will receive a new lease of life. Finally, it is important to note that development of other infrastructures such as roads, bridges etc. are not bad but only an educated population can build effective and lasting infrastructure and only the healthy can use power, bridges and roads and be able to develop policies that can move the nation forward and make the citizens competitive in the world order. Government is advised to improve funding in the education and health sectors if they want to leverage on these sectors for rapid socio-economic development. This would reduce brain drain in these sectors and medical tourism.

\section{Bibliography}

Adedigba, A. "2019 Budget Buhari Propose N462 billion for Education" Premium Times, 18 Dec. 2018, https://www premiumtimes.ng.com. (Last accessed $16^{\text {th }}$ February, 2019).

Aderemi, O., “A Look at the Key Figures in Nigeria's 2019 Budget”, https://wwwpulse.ng/finance (Last accessed $16^{\text {th }}$ February 2019).

Adinma E.D. and Adinma B.J., "Community Based Healthcare Financing: An Untapped Option to a More Effective Healthcare Funding in Nigeria”, Niger Med. Journal (2010) Vol.51, Pp95-100. 
Akpoghome, T.U., "Examining the Protection of Access to and Delivery of Healthcare by the National Health Act 2014", Advances in Social Sciences Research Journal (2018), Vol. 5, Issue 6, Pp521535 at 522 .

Article 16 (1) (2) African Charter on Human and Peoples Right (Ratification and Enforcement Procedure) Act, Cap A 9 LFN, 2004.

Article 17(1), African Charter on Human and Peoples Right (Ratification and Enforcement Procedure) Act, Cap A 9 LFN, 2004.

Atagboro, E., "Due Process Mechanisms and Fraudulent Practices in Nigeria Public Sector", Acta Universitatis Danubius. Administration (2015), Vol. 7, No. 1, p1.

Ayeloso, O. "Lagos Government Introduces Community Based Insurance Scheme", Nigerian Tribune, $13^{\text {th }}$ April 2011, http://www.tribune.com.ng/index.php/insurance/20352-lagos-gove-introduces-co mmunity-based-insurance-scheme. (Last accessed 15th February, 2019).

Babayemi, O., "Public Healthcare Financing in Nigeria: Which Way Forward?" Ann Nigeria Med (2012) Vol. 6, Issue Pp4-10 at 3,

https://www.anmjournal.com/articles.asp?2012/6/14/100199. (Last accessed 1st February 2019).

Bature, B and Orjime, M., "UNESCO Disburses N500, 000 Loan to Young Nigerians", Leadership Newspapers, 20 August 2018, http://www.leadership.ng/2018/08/20/UNESCO-disburses-500000-1 oan-to-young-nigerians. (Last accessed 15th February 2019).

Christiansen J. et al "The Effect of IPSAS on Reforming Governmental Financial Reporting: An International Comparison", International Review of Administrative Sciences, (2013), Vol. 76, p 537534

Dada, J. O., "Human Capacity building Challenges towards Improved Service Delivery in Africa", http://www.unpan1.un.org/aapam/unpan025978..../ (Last accessed 16 ${ }^{\text {th }}$ February, 2019).

Dike, V. E, “Governance and Nigeria's Weak Institutions: Is the 2020 Project Achievable”, http://www. gamji.com/article8000/NEWS8396.htm (Last accessed $5^{\text {th }}$ February, 2019).

Eke, M., "Challenges of Healthcare Financing in Nigeria", https://www.punchng.com/challenges-of-he althcare-financing-in-nigeria/ (Last accessed $1^{\text {st }}$ February, 2019).

Ezekwesili, O., "Due process Mechanism and Digital Opportunities", Paper presented. to the University Community at Princess Alexandria Auditorium, University of Nigeria, Nsukka, 2005.

Financial Reporting Council (FRC), http://www.financialrepoirtingcouncil gov.ng (Accessed $16^{\text {th }}$ February 2019).

Halidu, I. A, "The Allocative and Accountability Aspects of the Public Budget in Nigeria", being a paper presented at National Population Commission Workshop, (1991)

Hornby, A.S. Oxford Advanced Leaner's Dictionary of Current English, $8^{\text {th }}$ ed., (Oxford: 2009) p82.

International Public Sector Accounting Standing (IPSAS), https://www.eprints.convenantuniversity.ed uc.ng. (Accessed $16^{\text {th }}$ February 2019).

Jimoh, A., "50,000 to Benefit from Community Health Insurance Scheme in Kwara", The Nation, $4^{\text {th }}$ July 2009. http://www.thenationonlineng.net/web2/articles/5669/1/5000-to-benefit-from-communi ty-health-insurance-scheme-in-kwara/page/1.html. (Last accessed 15th February, 2019).

Kofele-Kale, $N$, The International Law of Responsibility for Economic Crimes: Holding State Officials Individually Liable for Acts of Fraudulent Enrichment, (Hampshire: 2006). 
Leadership Editors, "Budget 2018: Education and Health Sector", The Punch, June 1 2018, https://ww w.leadership.ng/2018/06/01/budget-2018-education-and-health-sector/ (Accessed 5th February 2019).

National Control Mechanisms, Transparency, Non Discrimination and Procurement, https://www.devel opentfinace.un.org/natural-control-mechnaimsms-transparency-non-discrimination-and-procureme nt/ (Accessed 1st February, 2019).

National Planning Commission, The Official Development Assistance Policy 2018, (Abuja: National Planning Commission; 2008).

Ndujihe, C., "Education in Free Fall: FG to Declare Emergency”, http://www.vanguardngr.com/2018/0 4/education-free-fall-government-to-declare-emergency/ (Last accessed $2^{\text {nd }}$ February, 2019).

Nwafor, P., Education Sector gets Paltry N3.9 trillion out of N55.19 trillion in Ten Years" http://www.v anguadngr.com. (Last accessed $16^{\text {th }}$ February, 2019).

Obokoh, A., 'Health Sector in 2019: Nigeria to Witness Big Initiatives, Improved Cancer Care-UHC", Business Day (Nigeria) 4 Jan 2019, https://www.presredader.com/nigeria (Last accessed $16^{\text {th }}$ February, 2019).

Okoro, S.C. and Okafor, G.O., "The Challenges of Public Sector Audit as an Effective Accountability Tool in PPP Arrangements in Nigeria", https:/www.researchgate.net/publication/228285881_the_c hallenges_of_Public_Sector_Audit_as_an_Effective_Accountability_Tool_in_PPP_Arrangement in_Nigeria. (Last accessed 2nd February 2019).

Olayinka, E et al, "International Public Sector Accounting Standards (IPSAS) Adoption and Quality of Financial Reporting in the Nigerian Public sector", ESUT Journal of Accountancy (2016), Vol. 7, No. 2, p 23.

Order XIII, Rule 97(5) of the Senate Standing Orders 2007 as amended.

Organization for Economic Co-operation and Development (OECD), Integrity in Public Procurement: Good Practice from $A-Z$ (France: DECD Publications; 2007).

Otunla, J. "Federal Government Sets December Deadline for IPSAS Adoption", (2012) http://www.thi sdaylive.com (Last accessed $16^{\text {th }}$ February 2019).

Owete, F et al "Special Report: How National Assembly's Public Account Committee Engage in Massive Money Laundering” January 24 2016, Premium Times http://www.premiuntimesng.com (Last accessed $16^{\text {th }}$ February 2019).

Section 1(3) CFRN 1999 as amended 2011.

Section 6 (6) (c) CFRN 1999 as amended 2011.

Section 17(3) (d) CFRN 1999 as amended 2011.

Sections 18(1) (2) (3) (a)-(d), CFRN as amended 2011.

Section 85 (4) CFRN 1999 as amended 2011.

Section 85 (5) CFRN 1999 as amended 2011.

Section 85 (6) CFRN 1999 as amended 2011.

Section 85(2) CFRN 1999 as amended 2011.

Section 85(5) CFRN 1999 as amended 2011

Section 86 CFRN (1999) as amended 2011.

Section 126 CFRN (1999) as amended 2011. 
Section 126, 127 and 128 CFRN 1999 as amended 2011.

Section 162(1) CFRN 1999 as amended 2011.

Section 162(2) CFRN 1999 as amended 2011.

Section 24 Finance (Control and Management) Act 1958.

Section 2, National Health Act, 2014.

Section 3 (1) (2) (a)-(d) National Health Act 2014.

Section 3 (3) National Health Act 2014.

Section 11 (1) (2) (a)-(c) National Health Act, 2014.

Section 11 (3) (a) National Health Act 2014.

Section 11(3) (b) National Health Act, 2014. It provides that 20 percent of the Basic Health Care provision fund shall be used to provide essential drugs, vaccines and consumables for eligible primary healthcare facilities. 11 (3) (c): 15 percent of the fund shall be used for the provision and maintenance of facilities, equipment and transport for eligible PHC facilities. (d) 10 percent of the fund shall be used for Emergency Medical Treatment of Human Resources for the PHC; and (e) 5 percent of the fund shall be used for Emergency Medical Treatment to be administered by a committee appointed by the National Council on Health.

Section 11 (5) (a)-(b) National Health Act 2014.

Section 11 (6) National Health Act, 2014.

Section 11 (7) National Health Act, 2014.

Section 4, Public Accounts Committee Act, 1987.

The Financial Reporting Council (FRC) of Nigeria Act No. 6, 2011.

The Incheon Declaration

The National Health Insurance Scheme (NHIS) was established by the Federal Government via Act 35 of 1999.

Torulagha, P. S., "The Corrosive Effect of Corruption on Nigerian Educational System", https://www.g anji.com. (Last accessed $16^{\text {th }}$ February, 2019).

Udeh, F. and Sopekan, S, “Adoption of IPSAS and the Quality of Public Sector Financial Reporting in Nigeria, Research Journal of Finance and Accounting, (2015), Vol.6, No. 20, Pp 1-9.

UNECO Promises Continued Support for Nigeria's Education; PM News $6^{\text {th }}$ Feb 2018, https://www.p mnewsnigeria.com (Last accessed $15^{\text {th }}$ February 2019).

World Bank, Financing Healthcare in Developing Countries: An Agenda for Reform (Washington DC: 1987). 